\title{
STATUS PERIODONTAL DAN KEBUTUHAN PERAWATAN PADA USIA LANJUT
}

\author{
${ }^{1}$ Reyna Agnes Nastassia Lumentut \\ ${ }^{2}$ Paulina N. Gunawan \\ ${ }^{3}$ Christy N. Mintjelungan
}

\author{
${ }^{1}$ Kandidat skripsi Program Studi Kedokteran Gigi \\ Fakultas Kedokteran Universitas Sam Ratulangi Manado \\ ${ }^{2}$ Bagian Ilmu Kesehatan Gigi Anak Program Studi Kedokteran Gigi \\ Fakultas Kedokteran Universitas Sam Ratulangi Manado \\ ${ }^{3}$ Bagian Ilmu Kesehatan Gigi Masyarakat Program Studi Kedokteran Gigi \\ Fakultas Kedokteran Universitas Sam Ratulangi Manado \\ Email: reynastassialumentut@gmail.com
}

\begin{abstract}
Elderly is a phase of declinemind and physical abilities caused by various degenerative diseases, environmental conditions and lifestyles. Changes that occur can lead the elderly to become susceptible to various diseases and one of it in oral is periodontal disease. The purpose of this research is to find out description of periodontal status and treatment need on elderly.This research is a descriptive research of Cross Sectional Study. The research did in the village of Ratatotok Muara with the community sample aged 55 years as many as 41 responden.Periodontal status examination performed by using an index of the WHO Community periodontal index of treatment needs (CPITN).Results showed that there was no healty periodontal, 1 person $(2,44 \%)$ had bleeding on probing, 17 person (41,46\%) have calculus, 19 orang $(46,34 \%)$ had periodontal pocket $4-5 \mathrm{~mm}$ and patient with periodontal pocket $\geq 6 \mathrm{~mm}$ were 4 person $(9,76 \%)$.
\end{abstract}

Key words: Elderly, periodontal disease, CPITN.

Abstrak: Usia lanjut adalah fase menurunnya kemampuan akal dan fisik akibat berbagai penyakit degeneratif, kondisi lingkungan serta gaya hidup. Perubahan yang terjadi mengakibatkan usia lanjut rentan terhadap berbagai penyakit termasuk penyakit periodontal. Tujuan dari penelitian ini yaitu untuk mengetahui gambaran status periodontal dan kebutuhan perawatan periodontal pada usia lanjut. Penelitian ini merupakan suatu penelitian deskriptif dengan pendekatan Study Cross Sectional.Penelitian dilakukan di desa Ratatotok Muara dengan sampel masyarakat yang berusiæ 55 tahun sebanyak 41 orang. Pemeriksaan status periodontal dilakukan dengan menggunakan indeks dari WHO yaitu Community index of periodontal treatment needs (CPITN). Hasil penelitian menunjukkan bahwa tidak ditemukan periodontal sehat, 1 orang (2,44\%) yang mengalami perdarahan pada saat probing, 17 orang $(41,46 \%)$ yang memiliki karang gigi, 19 orang $(46,34 \%)$ yang mengalami poket periodontal 4-5 mm dan sebanyak 4 orang (9,76\%) yang mengalami poket periodontal $\geq 6 \mathrm{~mm}$.

Kata kunci : Usia lanjut, penyakit periodontal, CPITN. 
80 Jurnal e-GiGi (eG), Volume 1, Nomor 2, September 2013, hlm. 79-83

Penyakit periodontal adalah penyakit yang kehilangan struktur kolagennya pada daerah yang menyangga gigi, sebagai respon dari akumulasi bakteri di jaringan periodontal. Penyakit periodontal merupakan penyakit infeksi yang menyerang gingiva dan jaringan pendukung gigi lainnya, jika tidak dilakukan perawatan yang tepat dapat mengakibatkan kehilangan gigi. Akumulasi bakteri plak pada permukaan gigi merupakan penyebab utama penyakit periodontal. Di Indonesia penyakit periodontal menduduki urutan ke dua yaitu mencapai 96,58\%. Berdasarkan Riset Kesehatan Dasar (RISKESDAS) tahun 2007 masalah gigi dan mulut termasuk penyakit periodontal di Sulawesi Utara yaitu 29,8\%.,

Usia lanjut merupakan istilah bagi orang-orang yang mengalami masalah secara fisik, biologik, psikologik dan sosial. Usia lanjut mengalami proses degenerasi pada berbagai tingkatan yang menyebabkan penurunan fungsi organ-organ tubuh. Penurunan fungsi ini mengakibatkan orang usia lanjut menjadi rentan terhadap berbagai penyakit, termasuk penyakit jaringan periodontal pada rongga mulut., ${ }^{3,4}$ Jaringan periodontal usia lanjut mengalami perubahan akibat dari proses penuaan. Perubahan yang terjadi apabila tidak dicegah menyebabkan penyakit periodontal semakin parah.

Penelitian yang dilakukan oleh WHO tentang prevalensi penyakit periodontal pada usia lanjut di Chicago Amerika Serikat tahun 2010 menunjukkan prevalensi penyakit periodontal mengalami peningkatan pada usia lanjut yaitu 70,1\%. ${ }^{5}$ Kerusakan jaringan periodontal meningkat sejalan dengan bertambahnya usia. Berbagai perubahan yang terjadi pada usia lanjut mengakibatkan lemahnya daya tahan jaringan periodontal terhadap berbagai iritasi, terutama bakteri plak.

Survei awal yang dilakukan di desa Ratatotok Muara, didapatkan sarana kesehatan gigi dan mulut di desa Ratatotok Muara ini kurang memadai karena Pusat Kesehatan Masyarakat (Puskesmas) dan Rumah Sakit tidak memiliki tenaga dokter gigi maupun perawat gigi sehingga tidak ada usaha promotif dan preventifmengenai kesehatan gigi dan mulut.

\section{METODE PENELITIAN}

Jenis penelitian ini merupakan penelitian deskriptif. Penelitian dilakukan di desa Ratatotok Muara kabupaten Minahasa Tenggara pada bulan April tahun 2013. Populasi pada penelitian ini yaitu masyarakat desa Ratatotok Muara yang berusia $\geq 55$ tahun berjumlah 50 orang. Kriteria inklusi untuk penelitian ini yaitu bersedia dengan sukarela untuk dijadikan sebagai subjek penelitian dengan menandatangani informed consent, dapat membuka mulut dengan baik, bersifat kooperatif dan terdapat gigi indeks disetiap sekstan. Subjek penelitian yang sudah kehilangan semua gigi geliginya, tidak dapat berkomunikasi dengan baik dan memiliki riwayat penyakit sistemik yaitu Diabetes Mellitus dimasukkan dalam kriteria eksklusi. Metode pengambilan sampel yaitu Total Sampling.

Pengambilan data dilakukan dengan cara memasuki rumah warga dari satu rumah ke rumah lain. Responden yang bersedia untuk dijadikan subjek penelitian dipersilahkan duduk kemudian dimintakan untuk membuka mulut lalu dilakukan pemeriksaan kedalaman periodontal dengan menggunakan probe periodontal.

Pemeriksaan dilakukan dengan cara probing pada setiap indeks gigi dengan menggerakkan probe periodontal ke sekeliling gigi untuk menilai enam titik disekitar gigi, yaitu : mesiofasial, midfasial, distofasial juga ditempat sejenis aspek lingual dan palatal. Temuan paling parah dicatat sebagai skor sekstan menurut pengukuran CPITN. Skor penilaian akan menunjukkan juga kriteria untuk indeks kebutuhan perawatan yang dibutuhkan (Tabel 1).

\section{HASIL PENELITIAN}

Penelitian ini dilakukan di daerah pesisir pantai desa Ratatotok Muara yang terletak di kecamatan Ratatotok, kabupaten Minahasa Tenggara. Desa Ratatotok Muara merupakan hasil pemekaran dari desa Ratatotok Timur.subjek penelitian yang sesuai kriteria inklusi yaitu 41 orang usia lanjut yang tinggal di desa Ratatotok Muara. 
Karakteristik subjek penelitian berdasarkan distribusi umur terlihat pada tabel 2.

Tabel 1. Kriteria untuk indeks kebutuhan perawatan

\begin{tabular}{|c|c|c|}
\hline Skor & Status & Perawatan \\
\hline 0 & Sehat & $\begin{array}{l}\text { Tidak membutuh- } \\
\text { kan perawatan }\end{array}$ \\
\hline 1 & Perdarahan & $\begin{array}{l}\text { Perbaikan oral } \\
\text { hygiene personal }\end{array}$ \\
\hline 2 & Adanya kal & $\begin{array}{l}\text { rsihan gigi } \\
\text { al hygiene }\end{array}$ \\
\hline 3 & $\begin{array}{l}\text { Period } \\
\geq 4-5\end{array}$ & $\begin{array}{l}\text { Pembersihan gigi } \\
\text { dan oral hygiene }\end{array}$ \\
\hline 4 & $\begin{array}{l}\text { Periodontal poket } \\
\geq 6 \mathrm{~mm}\end{array}$ & $\begin{array}{l}\text { Perawatan yang } \\
\text { lebih kompleks }\end{array}$ \\
\hline
\end{tabular}

Tabel 2. Subjek penelitian berdasarkan umur

\begin{tabular}{ccc}
\hline Umur (Tahun) & $\mathbf{n}$ & $\mathbf{\%}$ \\
\hline $55-59$ & 21 & 51,22 \\
$60-64$ & 10 & 24,40 \\
$65-69$ & 4 & 9,76 \\
$70-74$ & 3 & 7,31 \\
$75-79$ & 3 & 7,31 \\
\hline Total & 41 & 100,00 \\
\hline
\end{tabular}

Tabel 3 di atas menunjukkan bahwa karakteristik subjek penelitian berdasarkan umur yang dibagi menjadi lima kelompok usia lanjut terdiri dari 21 orang $(51,22 \%)$ berumur 55-59 tahun, 10 orang $(24,40 \%)$ berumur 60-64 tahun, 4 orang $(9,76 \%)$ berumur 65-69 tahun, 3 orang $(7,31 \%)$ berumur 70-74 tahun dan umur 75-79 tahun yaitu 3 orang (7,31\%).

Hasil pemeriksaan dengan menggunakan CPITN digunakan untuk mengukur kondisi jaringan periodontal dan bertujuan untuk mengetahui kebutuhan perawatan periodontal subjek penelitian. Tabel 3 menunjukkan status periodontal berdasarkan pengukuran CPITN.

Tabel 3. Status periodontal berdasarkan pengukuran CPITN

\begin{tabular}{ccc}
\hline Skor CPITN & n & $\mathbf{\%}$ \\
\hline 0 & - & - \\
1 & 1 & 2,44 \\
2 & 18 & 43,90 \\
3 & 18 & 43,90 \\
4 & 4 & 9,76 \\
\hline Total & 41 & 100,00 \\
\hline
\end{tabular}

Status periodontal berdasarkan pengukuran CPITN pada tabel 4 menunjukkan bahwa 1 (2,44\%) orang mengalami perdarahan (skor 1), 18 (43,90\%) orang memilki karang gigi (skor 2), 18 (43,90\%) orang mengalami poket periodontal 4-5 mm (skor 3) dan $4(9,76 \%)$ orang mengalami poket periodontal $\geq 6 \mathrm{~mm}$ (skor 4). Jumlah dan persentase status periodontal terbanyak terdapat pada skor 2 dan skor 3 yaitu memiliki karang gigi dan mengalami poket periodontal 4-5 mm sebanyak 18 orang (43,90\%).

Tabel 4. Status periodontal dari skor CPITN tertinggi berdasarkan kelompok umur usia lanjut

\begin{tabular}{|c|c|c|c|c|c|c|c|}
\hline \multirow{3}{*}{$\begin{array}{l}\text { Kelompok Umur } \\
\text { (Tahun) }\end{array}$} & \multicolumn{6}{|c|}{$\begin{array}{l}\text { Skor } \\
\text { CPITN }\end{array}$} & \multirow{2}{*}{ Total } \\
\hline & & 0 & 1 & 2 & 3 & 4 & \\
\hline & n & $\%$ & n $\%$ & $\%$ & n $\%$ & n $\%$ & n $\%$ \\
\hline $55-59$ & & - & $1(2,44)$ & $7(17,07)$ & $12(29,26)$ & $1(2,44)$ & $21(51,22)$ \\
\hline $60-64$ & & - & - & $5(12,19)$ & $3(7,31)$ & $2(4,87)$ & $10(24,40)$ \\
\hline $65-69$ & & - & - & $4(9,76)$ & - & - & $4(9,76)$ \\
\hline $70-74$ & & - & - & - & $3(7,31)$ & - & $3(7,31)$ \\
\hline $75-79$ & & - & - & $2(4,87)$ & - & $1(2,44)$ & $3(7,31)$ \\
\hline Total & & - & $1(2,44)$ & $18(43,90)$ & $18(43,90)$ & $4(9,76)$ & $41(100,00)$ \\
\hline
\end{tabular}


82 Jurnal e-GiGi (eG), Volume 1, Nomor 2, September 2013, hlm. 79-83

Tabel 4 dapat dilihat bahwa untuk kelompok usia 55-59 tahun paling banyak mengalami kerusakan jaringan periodontal karena adanya poket 4-5 mm yaitu 12 orang (29,26\%), sedangkan paling sedikit mengalami kerusakan jaringan periodontal karena adanya perdarahan pada saat probing yaitu 1 orang $(2,44)$ dan mengalami kerusakan jaringan periodontal terparah karena adanya poket $\geq 6 \mathrm{~mm}$ yaitu 1 orang (2,44\%). Kelompok usia 60-64 tahun paling banyak mengalami kerusakan jaringan periodontal karena memiliki karang gigi yaitu 5 orang $(12,19 \%)$, paling sedikit mengalami kerusakan jaringan periodontal karena adanya poket $\geq 6 \mathrm{~mm}$ yaitu 2 orang (4,87\%). Pada kelompok usia 65-69 tahun mengalami kerusakan jaringan periodontal karena memiliki karang gigi yaitu 4 orang (9,76\%). Kelompok usia 70-74 tahun mengalami kerusakan jaringan periodontal karena adanya poket 4-5 mm. Kemudian pada kelompok usia 75-79 tahun mengalami kerusakan jaringan periodontal karena memiliki karang gigi yaitu 2 orang $(4,87 \%)$ dan adanya poket $\geq 6 \mathrm{~mm}$ yaitu 1 orang $(2,44 \%)$.

\section{PEMBAHASAN}

Hasil pemeriksaan status periodontal pada kelompok 55-59 tahun paling banyak mengalami periodontal poket 4-5 mm (skor 3) yaitu sebanyak 12 orang (29,26\%), kelompok 60-64 tahun yang memiliki karang gigi (skor 2) yaitu sebanyak 5 orang (12,19\%), kelompok 65-69 tahun memiliki karang gigi (skor 2) sebanyak 4 orang (9,76\%), kelompok 70-74 tahun mengalami periodontal poket 4-5 mm (skor 3) yaitu sebanyak 3 orang $(7,31 \%)$ dan kelompok 75-79 tahun memiliki karang gigi (skor 2) sebanyak 2 orang $(4,87 \%)$ sedangkan pada kelompok usia ini mengalami kerusakan jaringan periodontal terparah karena adanya periodontal poket $\geq 6 \mathrm{~mm}$ (skor 4) yaitu 1 orang (2,44\%). Hasil diatas menunjukkan bahwa pada kelompok umur 55-59 tahun paling banyak mengalami periodontal poket 4-5 mm (skor 3) yaitu sebanyak 12 orang (29,26\%). Keparahan penyakit periodontal lebih banyak terjadi pada kelompok umur tersebut dikarenakan jumlah sampel dari kelompok umur tersebut paling banyak dibandingkan kelompok umur lain. Distribusi status periodontal dari skor CPITN tertinggi berdasarkan umur menunjukkan semua kelompok umur usia lanjut menderita penyakit periodontal, hal ini sesuai dengan penelitian yang dilakukan Sampara A.W pada tahun 2012 di Rumah Sakit Gigi dan Mulut Unhas Kandea yang menunjukkan bahwa pada usia lanjut mengalami penyakit periodontal stadium lanjut dan juga ditemukan karang gigi akibat dari tidak dapat menjaga kesehatan gigi dengan baik. ${ }^{6}$ Hasil penelitian ini diperkuat oleh penelitian Indriwati Tjahja tahun 2007 dilakukan di 20 Puskesmas Jakarta yang menunjukkan bahwa ada hubungan yang signifikan antara usia dengan status kesehatan gigi dan mulut. ${ }^{7}$ Teori mengenai penuaan pada jaringan periodontal juga menunjukkan bahwa semakin bertambahnya usia lebih berpotensi akan mengalami kehilangan perlekatan jaringan dan hal ini juga akan mengakibatkan semakin meningkat kejadian kehilangan gigi di usia lanjut. ${ }^{8}$ Hal inilah yang menjadi faktor risiko terjadinya penyakit periodontal diusia lanjut.

Hasil pemeriksaan ini menujukkan bahwa seluruh responden menderita penyakit periodontal. Kebanyakan responden didapati mengalami periodontal poket 4-5 mm yaitu 43,90\%, 43,90\% memiliki karang gigi dan keadaan paling parah yaitu periodontal poket $\geq 6 \mathrm{~mm}$ sebanyak $9,76 \%$. Dilihat dari kondisi jaringan periodontal secara keseluruhan mengalami kerusakan, hal tersebut menunjukkan bahwa seluruh responden membutuhkan perawatan periodontal. Hasil pemeriksaan menunjukkan bahwa responden membutuhkan paling banyak perawatan pembersihan gigi seperti penyikatan gigi dibawah pengawasan dokter gigi dan perbaikan oral hygiene yaitu 46,34\% dan membutuhkan perawatan periodontal yang lebih kompleks seperti skeling, penyerutan akar dengan anastesi lokal dan dengan atau tanpa prosedur bedah yaitu 9,76\%. Tingginya kebutuhan perawatan periodontal berdampak pada tingginya kebutuhan tenaga perawat gigi dan dokter 
gigi khususnya di desa Ratatotok Muara.

Dilihat dari kondisi kerusakan periodontal dan kebutuhan perawatan yang semakin meningkat menunjukkan hal ini sejalan dengan teori yang menyatakan bahwa umur menjadi salah satu faktor resiko terjadinya penyakit periodontal. Semakin bertambahnya usia semakin tinggi tingkat keparahan penyakit periodontal dan kebutuhan akan perawatan periodontal juga semakin meningkat. ${ }^{9}$

\section{SIMPULAN DAN SARAN}

Penelitian ini menunjukkan bahwa status periodontal pada usia lanjut paling banyak mengalami keparahan penyakit periodontal pada skor 2 dan skor 3 yaitu 18 orang (43,90\%). Kebutuhan perawatan jaringan periodontal secara menyeluruh pada usia lanjut di desa Ratatotok Muara yaitu instruksi menjaga oral hygiene personal, membutuhkan perawatan pembersihan gigi seperti penyikatan gigi personal.

Bagi dinas kesehatan setempat perlu adanya kerjasama dan dukungan pemerintah dalam penyediaan tenaga dokter gigi dan perawat gigi di desa Ratatotok Muara dan peralatan yang memadai untuk meningkatkan pelayanan kesehatan gigi dan mulut khususnya dalam usaha promotif dan preventif bagi kesehatan gigi dan mulut usia lanjut. Masyarakat desa Ratatotok Muara lebih memperhatikan, menjaga dan memelihara kesehatan gigi dan mulut serta jaringan sekitarnya dengan melakukan kunjungan yang rutin ke dokter gigi atau perawat gigi setempat.

\section{DAFTAR PUSTAKA}

1. Tampubolon SN. Dampak Karies dan Penyakit Periodontal Terhadap Kualitas Hidup [homepage on the Internet]. 2005 [cited 2013 Jan 28]. Available from URL: http://library.usu.co.id

2. Riset Kesehatan Dasar (RISKESDAS) 2007. Laporan Penelitian. Departemen Kesehatan Republik Indonesia [homepage on the Internet]. 2008 [cited 2013 Jan 28]. Available from URL: http:www.scribd.com/ doc/82922543/laporanNasional-Riskesdas2007.

3. Saptorini, Kriswiharsi K. Poket Periodontal pada Lanjut Usia Di Posyandu Lansia Kelurahan Wonosari Kota Semarang [homepage on the Innternet]. 2011 [cited 2013 Maret]. Available from URL: http://journal.unsil.ac.id/jurnal/prosiding/9/9 Kriswiharsi_28.pdf

4. Thalib B. Status Jaringan Periodontal dan Kebutuhan Perawatan Jaringan Periodontal pada Manula Suku Bugis dan Suku Mandar. Dentofasial Jurnal Kedokteran Gigi. 2007;6(1):57-51.

5. Thornton E, Genco RJ. Prevalence of Periodontitis in Adults in the United States: 2009 and 2010. J Dent Res [serial online]. 2012 [cited 2013 April 11]; Available from URL:http://www.perio.org/consumer/cdcstudy.htm.

6. Sampara AW. Prevalensi Poket Periodontal di Rumah Sakit Gigi dan Mulut Kandea [homepage on the Internet]. 2012 [cited 2013 Apr 29]. Available from URL: http://repository.unhas.ac.id

7. Tjahja I, Ghani L. Status Kesehatan Gigi dan Mulut Ditinjau dari Faktor Individu Pengunjung Puskesmas DKI Jakarta Tahun 2007 [serial online]. 2010 [cited 2013 April 29]; 38(2):58-67. Available from URL: isjd.pdii.lipi.go.id/ admin/jurnal/382105266_0125-9695.pdf.

8. Huttner E A. Effects of Human Aging on Periodontal Tissues [serial online]. 2009 [cited 2013 Mei 22]; 29(4):151-152. Available from URL :web.ebscohost.com

9. Sondang P, Hamada T. Fairway to Oral Health in General Practice [skripsi]. Medan: USU press; 2008; 1-2, 25-37. 